\title{
Genetic variability of Hypostomus (Teleostei, Loricariidae) from the Ribeirão Maringá, a stream of the upper Rio Paraná basin, Brazil
}

\author{
Suzana de Paiva ${ }^{1}$, Erasmo Renesto ${ }^{1}$ and Cláudio Henrique Zawadzki ${ }^{2}$ \\ ${ }^{1}$ Universidade Estadual de Maringá, Departamento de Biologia Celular e Genética, Núcleo de Pesquisas em \\ Limnologia, Ictiologia e Aqüicultura, Maringá, PR, Brazil. \\ ${ }^{2}$ Universidade Estadual do Centro-Oeste, Departamento de Ciências Biológicas, Guarapuava, PR, Brazil.
}

\begin{abstract}
Hypostomus strigaticeps and two morphotypes of Hypostomus were collected from Ribeirão Maringá, a small tributary of the Rio Pirapó, an effluent of the upper Rio Paraná. The three populations were analyzed by allozyme electrophoresis that allowed the scoring of 25 loci from 14 enzyme systems. Heterozygosity values $\left(H_{e}\right)$ were 0.028 in H. strigaticeps, 0.027 in Hypostomus sp. 1 and zero in Hypostomus sp. 2. Several diagnostic loci and fixed differences were observed for each population at loci Acp-A, Gcdh-A and Mdhp-A. Thus, all populations were genetically distinct, although there were many common alleles. The unbiased genetic identities of Nei $(I)$ were estimated as 0.780 for Hypostomus sp. 1 and $H$. strigaticeps, 0.357 for $H$. strigaticeps and Hypostomus sp. 2 and 0.322 for Hypostomus sp. 1 and Hypostomus sp. 2. The data indicate that the two morphotypes are distinct species from Hypostomus strigaticeps.
\end{abstract}

Key words: allozymes, heterozygosity, Hypostomus, Loricariidae, systematic.

Received: March 11, 2004; Accepted: February 2, 2005.

\section{Introduction}

The loricariid genus Hypostomus is considered one of the most complex of the Neotropical ichthyofauna (Gosline, 1947; Reis et al., 1990; Mazzoni et al., 1994). In the upper Rio Paraná basin, which is the stretch of the Paraná hydrographic basin above Itaipu Dam, there are several small and medium-sized tributaries whose ichthyofauna is usually isolated by biotic and abiotic factors. Furthermore, geographically close tributaries harbor different loricariid species, popularly known as cascudos. The usual absence of some headwater loricariid species in the main channel of great rivers could lead to the assumption that waterfalls at the mouth of the tributaries and the different ecological parameters of big rivers would act as barriers to many small and medium-length cascudos. At the same time, that geographical isolation of populations plays an important role in speciation, it can also lead to extinction of small populations. Therefore, characterization of the distribution and the genetic constitution of the many morphotypes of Hypostomus found in many headwaters of the upper Rio Paraná basin is required for future conservation guidelines. Nowadays, although several species of the

Send correspondence to Suzana de Paiva. Universidade Estadual de Maringá, Departamento de Biologia Celular e Genética, Av. CoIombo - 5790, 87020-900, 261-4740, Maringá, PR, Brazil. E-mail: suzanapaiva@yahoo.com.br. genus Hypostomus, such as H. regani (Ihering, 1905), $H$. ancistroides (Ihering, 1911) and H. margaritifer (Regan, 1907), are widespread and well characterized, many morphotypes are endemic to one or a few small tributaries of the upper Rio Paraná basin. Thus, while a taxonomical review is necessary, genetic works could improve the knowledge about the genetic variability and reproductive isolation among the many forms observed.

In the Ribeirão Maringá (Figure 1) there are three syntopic morphotypes belonging to the genus Hypostomus: H. strigaticeps (Regan, 1907) and two other populations, probably two non-described species. Reproductive isolation among populations has been investigated using the allozyme electrophoresis technique. This methodology has been used to discriminate known species (Zawadzki et al., 2001) and to reveal new species (Fisch-Muller et al., 2001) of Loricariidae and its strength is a focus on analysis of sympatric species. Thus, this work aims to verify the existence of reproductive isolation among these three populations found in Ribeirão Maringá as well as to discuss their genetic variability and the interpretation of allozyme data in the systematics of Hypostomus.

\section{Material and Methods}

From August, 2001 to April, 2002, 17 specimens of H. strigaticeps, 17 of Hypostomus sp. 1, and 13 of 


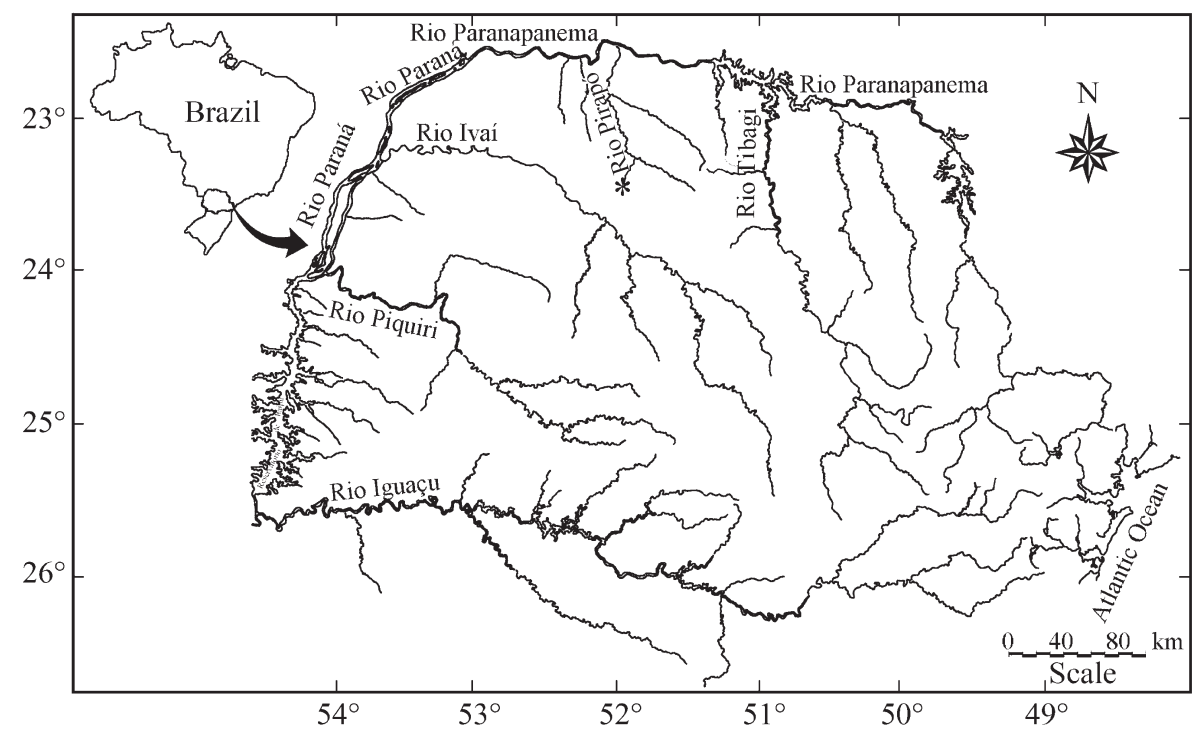

Figure 1 - Collection site of the three populations of Hypostomus from the Ribeirão Maringá (asterisk), Rio Pirapó, Rio Paranapanema, upper Rio Paraná basin.

Hypostomus sp. 2 were sampled in the Ribeirão Maringá, which is a small effluent of the Rio Pirapó, Rio Paranapanema, upper Rio Paraná basin. Samples of white skeletal muscle, liver and heart tissues were removed from the fishes immediately after capture. Tissues were stored in liquid nitrogen until analyses. Electrophoretic procedures were detailed in Zawadzki et al. (1999). The nomenclature used was proposed by the International Union of Biochemistry and Molecular Biology (1992). Data were analyzed using POPGENE 1.31 software (Yeh and Boyle, 1997). The genetic interpretation of the enzymatic patterns was based on the quaternary structure of the enzymes described by Ward et al. (1992).

Voucher specimens were deposited in the collection of Nupelia (Research Center in Ichthyology, Limnology and Aquaculture) of the State University of Maringá. Specimen list was arranged in the text as follows: museum acronym and catalogue number, number of specimens as a parenthetical remark, standard length range in millimeters, locality, collection date and collector.

\section{Voucher specimens}

Hypostomus strigaticeps: NUP 2831, (20), 75.45-

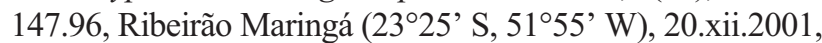
Cláudio H. Zawadzki and Weferson J. Graça; Hypostomus sp. 1: NUP 2830 (30), 53.32-88.98, Ribeirão Maringá (2325' S/51 $\left.55^{\prime} \mathrm{W}\right), 20 . x i 1.2001$, Cláudio H. Zawadzki and Weferson J. Graça; Hypostomus sp. 2: NUP 2832, (8), 113,36139,15 , Ribeirão Maringá $\left(23^{\circ} 25^{\prime}\right.$ S, $51^{\circ} 55^{\prime}$ W), 20.xii.2001, Cláudio H. Zawadzki and Weferson J. Graça.

\section{Results}

A total of 14 enzyme systems encoded by 25 loci were assayed for the three Hypostomus populations, allow- ing the detection of 52 alleles. Table 1 shows the enzymatic systems analyzed and Table 2 shows the allele frequencies of the three populations analyzed.

Several loci showed diagnostic alleles. The loci Acp-A, Gcdh-A and sMdhp-A were diagnostic for the three populations and can be elected as good genetic markers for a rapid discrimination among them. Furthermore, the alleles sAta-B- $a$, G3pdh-A- $b$, G3pdh-B- $b$, G6pdh-A- $b$, G6pdh-B- $b$, Gpi-A-c, Gpi-B- $b$, mIcdh-A-c, Ldh-A- $a$, Ldh-B- $a$, sMdh-B- $a$ and mMdhp-A- $b$ are exclusive to Hypostomus sp. 2. The allozyme encoded by the allele $a$ of locus Ldh-A in Hypostomus sp. 2 migrates to the same position of allele $b$ of locus Ldh-B in Hypostomus sp. 1 and $H$. strigaticeps (Figure 2). The allele Adh-A- $a$ distinguished Hypostomus sp. 1 from the other populations analyzed. In addition to loci Acp-A, Gcdh-A, sMdhp-A and Adh-A, Hypostomus sp. 1 and H. strigaticeps were discriminated by clear allele frequency differences at loci Gpi-A and mIcdh-A. No locus was consistently polymorphic for all populations. The loci mMdh-A, sMdh-A, Per-1, Per-2, Per-3 and Sod-A were monomorphic and similar for the three populations.

The genetic variability for the three populations is shown in Table 2. Six loci were polymorphic $\left(\mathrm{P}_{0.99}\right.$ criterion) in one or more populations (Table 2). The frequency of polymorphic loci ranged from zero in Hypostomus sp. 2 to 0.20 in Hypostomus sp. 1 and H. strigaticeps. The expected mean heterozygosity ranged from zero in Hypostomus sp. 2 to 0.028 in H. strigaticeps. All the polymorphic loci analyzed were in Hardy-Weinberg equilibrium. The unbiased genetic identity of Nei (1978) for the three populations is shown in Table 3. The most similar populations were H. strigaticeps and Hypostomus sp. 1 
Table 1 - Names, number of enzyme commission (E.C.n.), tissues, buffers, quaternary structure (Q.S) and number of loci of each enzyme of the three Hypostomus populations from the Ribeirão Maringá, upper Rio Paraná basin. $\mathrm{L}=$ liver; $\mathrm{M}=$ muscle; $\mathrm{H}=$ heart; TBE = Tris/borate/EDTA (pH 8.7) (Boyer et al. 1963); TC = Tris/citrate (pH 7.0) and TEM = Tris/EDTA/maleic (pH 7.4) (Shaw and Prasad 1970).

\begin{tabular}{|c|c|c|c|c|c|}
\hline Enzyme (Abbreviation) & E.C. $n^{\circ}$ & Tissue & Buffer & Q. S. & Loci \\
\hline Acid phosphatase (ACP) & 3.1.3.2 & $\mathrm{L}$ & $\mathrm{TC}$ & Dimeric & 1 \\
\hline Alcohol dehydrogenase (ADH) & 1.1.1.1 & $\mathrm{L}$ & TBE & Dimeric & 1 \\
\hline Aspartate transaminase (ATA) & 2.6.1.1 & $\mathrm{L}, \mathrm{H}, \mathrm{M}$ & TEM & Dimeric & 2 \\
\hline Glucose 1-dehydrogenase - NAD+(GCDH) & 1.1.1.118 & $\mathrm{L}$ & TEM & Dimeric & 1 \\
\hline Glycerol-3-phosphate dehydrogenase (G3PDH) & 1.1.1.8 & $\mathrm{L}, \mathrm{H}, \mathrm{M}$ & $\mathrm{TC}$ & Dimeric & 2 \\
\hline Glucose-6-phosphate dehydrogenase (G6PDH) & 1.1.1.49 & $\mathrm{L}$ & TBE & Tetrameric & 2 \\
\hline Glucose-6-phosphate isomerase (GPI) & 5.3 .1 .9 & $\mathrm{~L}, \mathrm{H}, \mathrm{M}$ & $\mathrm{TC}$ & Dimeric & 2 \\
\hline Isocitrate dehydrogenase - NADP+(ICDH) & 1.1 .1 .42 & $\mathrm{~L}, \mathrm{H}, \mathrm{M}$ & $\mathrm{TC}$ & Dimeric & 2 \\
\hline L-Lactate dehydrogenase (LDH) & 1.1 .1 .27 & $\mathrm{H}, \mathrm{M}$ & $\mathrm{TC}$ & Tetrameric & 2 \\
\hline Malate dehydrogenase (MDH) & 1.1 .1 .37 & $\mathrm{~L}, \mathrm{H}, \mathrm{M}$ & $\mathrm{TC}$ & Dimeric & 3 \\
\hline Malate dehydrogenase - NADP+(MDHP) & 1.1 .1 .40 & $\mathrm{~L}, \mathrm{H}, \mathrm{M}$ & $\mathrm{TC}$ & Tetrameric & 2 \\
\hline Peroxidase (PER) & 1.11.1.6 & $\mathrm{L}, \mathrm{H}$ & $\mathrm{TC}$ & Tetrameric & 3 \\
\hline Phosphoglucomutase (PGM) & 5.4 .2 .2 & $\mathrm{~L}, \mathrm{H}, \mathrm{M}$ & $\mathrm{TC}$ & Monomeric & 1 \\
\hline Superoxide dismutase (SOD) & 1.15 .1 .1 & $\mathrm{~L}, \mathrm{H}, \mathrm{M}$ & TBE & Dimeric & 1 \\
\hline
\end{tabular}

$(I=0.780)$ and the most divergent were Hypostomus sp. 1 and Hypostomus sp. $2(I=0.322)$.

\section{Discussion}

The mean genetic variability estimated for the three studied populations $(0.018)$ was considered quite below the mean found by Ward et al. (1992) for freshwater fishes $\left(H_{e}\right.$ $=0.051)$. In another allozyme survey carried out in the Ribeirão Keller, a tributary of the Rio Ivaí basin, Zawadzki et al. (2004a) found higher values of $\mathrm{He}$ for four morphotypes of the genus Hypostomus: 0.068 in $H$. hermanni (Ihering, 1905), 0.143 in Hypostomus sp. 1, 0.059 in Hypostomus sp. 2, and 0.091 in Hypostomus sp. 3. In addition to the higher mean expected heterozygosity found by those authors, $(0.088)$ it should be noted that the three non-described morphotypes were not the same as those studied in this work. Although the heterozygosity values of most species of Hypostomus fall into the Ward's average, some of them, such as $H$. margaritifer $\left(H_{e}=0.106\right)$, H. regani $\left(H_{e}=0.098\right)$, and Hypostomus sp. $1\left(H_{e}=0.107\right)$ from the Itaipu Reservoir show higher values (Zawadzki, 2001).

Contrary to these findings, the loricariid Neoplecostomus paranensis (Langeani, 1990) wich were restricted to small headwater streams presented zero $H_{e}$ values (Zawadzki et al., 2004b). Population isolation promoted by some efficient barrier was used to explain the unusual lack of genetic variability in $N$. paranensis. Here, the low heterozygosity values for $H$. strigaticeps and Hypostomus sp. 1 and the zero heterozygosity value found for Hypostomus sp. 2 also indicate that similar events can be acting to isolate these three morphotypes from other populations of Hypostomus. Consequently, isolated populations, especially small ones, may have their heterozygosity eroded by inbreeding process or by chance (Solé-Cava, 2001).

The recording of 17 loci as diagnostic genetic markers, $68 \%$ from the 25 studied loci, is strong evidence of the usefulness of allozyme data in the systematics of the loricariid genus Hypostomus as was pointed out by Zawadzki et al. (2000). According to Weber (2003), the genus Hypostomus comprises 107 valid species and shows a particularly high intraspecific variability in morphology and color pattern that prompted most of these species to be misunderstood in terms of variability. This phenomenon makes it impossible for most Neotropical ichthyologists to correctly identify Hypostomus morphotypes. Here, we highlight the potential use of allozyme data for the acquisition of genetic markers for some morphologically variable and syntopic Hypostomus populations.

Although Hypostomus strigaticeps and Hypostomus sp. 1 have light dots over a darker background and both of them fit the Hypostomus regani group of species sensu Muller and Weber (1992), for both, the dots can range from clear round to a striped pattern, and in Hypostomus sp. 1 these light markers may even be absent. Morphometrically, they diverge in dorsal-fin spine lengths that ranges from 1.65 to 1.82 in the pre-dorsal length in Hypostomus sp. 1 vs. 1.26 to 1.28 in $H$. strigaticeps.

Hypostomus sp. 1 and $H$. strigaticeps are distinguished, in addition to Acp-A, Gcdh-A and sMdhp-A, by different fixed alleles at locus Adh-A. Furthermore, differential expression was observed in LDH isozymes of Hypostomus sp. 1 that showed higher expression of locus 
Table 2 - Allele frequencies, sample number (n), number of alleles per locus (K), frequency of polymorphic loci ( $\left.\mathrm{P}_{0.99}\right)$, mean expected heterozygosity $\left(H_{e}\right)$, mean observed heterozygosity $\left(H_{o}\right)$ of Hypostomus strigaticeps and two morphotypes from Ribeirão Maringá.

\begin{tabular}{|c|c|c|c|c|}
\hline Loci & Allele & $\begin{array}{c}\text { H. Strigaticeps } \\
(\mathrm{n}=17)\end{array}$ & $\begin{array}{l}\text { Hypostomus sp. } \\
(\mathrm{n}=17)\end{array}$ & $\begin{array}{c}1 \text { Hypostomus sp. } 2 \\
(\mathrm{n}=13)\end{array}$ \\
\hline \multirow[t]{2}{*}{ sAta-A } & $a$ & 0.117 & 0.058 & $* * * *$ \\
\hline & $b$ & 0.882 & 0.941 & 1.000 \\
\hline \multirow[t]{3}{*}{ sAta-B } & $a$ & $* * * *$ & $* * * *$ & 1.000 \\
\hline & $b$ & 0.970 & 1.000 & $* * * *$ \\
\hline & $c$ & 0.029 & $* * * *$ & $* * * *$ \\
\hline \multirow[t]{3}{*}{ Acp-A } & $a$ & $* * * *$ & $* * * *$ & 1.000 \\
\hline & $b$ & $* * * *$ & 1.000 & $* * * *$ \\
\hline & $c$ & 1.000 & $* * * *$ & $* * * *$ \\
\hline \multirow[t]{2}{*}{ Adh-A } & $a$ & $* * * *$ & 1.000 & $* * * *$ \\
\hline & $b$ & 1.000 & $* * * *$ & 1.000 \\
\hline \multirow[t]{3}{*}{ Gcdh-A } & $a$ & $* * * *$ & 1.000 & $* * * *$ \\
\hline & $b$ & 1.000 & $* * * *$ & $* * * *$ \\
\hline & $c$ & $* * * *$ & $* * * *$ & 1.000 \\
\hline \multirow[t]{2}{*}{ G3pdh-A } & $a$ & 1.000 & 1.000 & $* * * *$ \\
\hline & $b$ & $* * * *$ & $* * * *$ & 1.000 \\
\hline \multirow[t]{2}{*}{ G3pdh-B } & $a$ & 1.000 & 1.000 & $* * * *$ \\
\hline & $b$ & $* * * *$ & $* * * *$ & 1.000 \\
\hline \multirow[t]{2}{*}{ G6pdh-A } & $a$ & 1.000 & 1.000 & $* * * *$ \\
\hline & $b$ & $* * * *$ & $* * * *$ & 1.000 \\
\hline \multirow[t]{2}{*}{ G6pdh-B } & $a$ & 1.000 & 1.000 & $* * * *$ \\
\hline & $b$ & $* * * *$ & $* * * *$ & 1.000 \\
\hline \multirow[t]{3}{*}{ Gpi-A } & $a$ & 1.000 & 0.218 & $* * * *$ \\
\hline & $b$ & $* * * *$ & 0.781 & $* * * *$ \\
\hline & $c$ & $* * * *$ & $* * * *$ & 1.000 \\
\hline \multirow[t]{2}{*}{ Gpi-B } & $a$ & 1.000 & 1.000 & $* * * *$ \\
\hline & $b$ & $* * * *$ & $* * * *$ & 1.000 \\
\hline \multirow[t]{3}{*}{ mIcdh-A } & $a$ & 0.088 & 0.941 & $* * * *$ \\
\hline & $b$ & 0.911 & 0.058 & $* * * *$ \\
\hline & $c$ & $* * * *$ & $* * * *$ & 1.000 \\
\hline
\end{tabular}

Ldh-A than the other populations of Hypostomus analyzed which showed no or very weak expression at this locus in the TC-7.0 buffer (Figure 2). Zawadzki et al. (1999) found, in three Hypostomus species from the Rio Iguaçu, a divergent expression pattern: in Hypostomus cf. commersoni (Valenciennes, 1840) and H. myersi (Gosline, 1947) the least anodal LDH-B was less stained and the most anodal LDH-A was the most stained; in Hypostomus derbyi (Haseman, 1911) the least anodal LDH-B was most stained and the most anodal LDH-A was weakly or not stained. Here, the LDH expression in Hypostomus sp. 2 is similar to that found in H. derbyi. However, in Hypostomus sp. 1 the least stained was not the least anodal but, instead, it was the most anodal. We have two possible explanations for this phenomenon, both isozymes encoded by these loci increased equally their anodal mobility and inverted their

\begin{tabular}{|c|c|c|c|c|}
\hline Loci & Allele & $\begin{array}{c}\text { H. Strigaticeps } \\
(\mathrm{n}=17)\end{array}$ & $\begin{array}{l}\text { Hypostomus sp. } 1 \\
\quad(\mathrm{n}=17)\end{array}$ & $\begin{array}{l}\text { Hypostomus sp. } 2 \\
(\mathrm{n}=17)\end{array}$ \\
\hline \multirow[t]{3}{*}{ sIcdh-A } & $a$ & 0.058 & $* * * *$ & $* * * *$ \\
\hline & $b$ & 0.941 & 0.970 & $* * * *$ \\
\hline & $c$ & $* * * *$ & 0.029 & 1.000 \\
\hline \multirow[t]{2}{*}{ Ldh-A } & $a$ & $* * * *$ & $* * * *$ & 1.000 \\
\hline & $b$ & 1.000 & 1.000 & $* * * *$ \\
\hline \multirow[t]{2}{*}{ Ldh-B } & $a$ & $* * * *$ & $* * * *$ & 1.000 \\
\hline & $b$ & 1.000 & 1.000 & $* * * *$ \\
\hline mMdh-A & $a$ & 1.000 & 1.000 & 1.000 \\
\hline sMdh-A & $a$ & 1.000 & 1.000 & 1.000 \\
\hline \multirow[t]{2}{*}{ sMdh-B } & $a$ & $* * * *$ & $* * * *$ & 1.000 \\
\hline & $b$ & 1.000 & 1.000 & $* * * *$ \\
\hline \multirow[t]{3}{*}{ sMdhp-A } & $a$ & $* * * *$ & $* * * *$ & 1.000 \\
\hline & $b$ & 1.000 & $* * * *$ & $* * * *$ \\
\hline & $c$ & $* * * *$ & 1.000 & $* * * *$ \\
\hline \multirow[t]{2}{*}{ mMdhp-A } & $a$ & 1.000 & 1.000 & $* * * *$ \\
\hline & $b$ & $* * * *$ & $* * * *$ & 1.000 \\
\hline Per-1 & $a$ & 1.000 & 1.000 & 1.000 \\
\hline Per-2 & $a$ & 1.000 & 1.000 & 1.000 \\
\hline Per-3 & $a$ & 1.000 & 1.000 & 1.000 \\
\hline \multirow[t]{3}{*}{ Pgm-A } & $a$ & 0.058 & 0.029 & $* * * *$ \\
\hline & $b$ & 0.911 & 0.970 & 1.000 \\
\hline & $\mathrm{c}$ & 0.029 & $* * * *$ & $* * * *$ \\
\hline Sod-A & $a$ & 1.000 & 1.000 & 1.000 \\
\hline K & - & $1.24(0.52)^{*}$ & $1.20(0.41)^{*}$ & $1.00(0.00)^{*}$ \\
\hline $\mathrm{P}_{0.99}$ & - & 20.0 & 20.0 & 00.0 \\
\hline$H_{o}$ & - & $0.021(0.053)^{*}$ & $0.022(0.088)^{*}$ & $0.000(0.000)^{*}$ \\
\hline$H_{e}$ & - & $0.028(0.062)^{*}$ & $0.027(0.074)^{*}$ & $0.000(0.000)^{*}$ \\
\hline
\end{tabular}

*Number in parentheses is the respective standard error.

staining intensity, or LDH-A was kept in the same position and only the LDH-B increased its mobility, since it is the most anodal and both maintained their expression intensity pattern. Murphy et al. (1996) showed that the LDH expression in different buffers. In Tris/Citrate $\mathrm{pH} 7.0$ buffer only the Ldh-B locus isozyme was stained for a variety of species. When these same organisms were run in a Tris/Citrate/Borate $\mathrm{pH} 8.2$ buffer, both the most anodal Ldh-A and the least anodal Ldh-B were equally expressed.

Hypostomus sp. 2 was the most divergent population and among the 25 loci analyzed it was distinguished by 12 fixed different alleles. Morphologically, Hypostomus sp. 2 is also easily distinguished, bears small dark dots on the body and head over a light background and is morphologically similar to Hypostomus ancistroides. Together with $H$. ancistroides, Hypostomus sp. 2 fits the Hypostomus 
Table 3 - Nei's unbiased genetic identity $I$ are shown above the diagonal and genetic distance $D$ are shown below the diagonal.

\begin{tabular}{lccc}
\hline Populations & H. strigaticeps & Hypostomus sp. 1 & Hypostomus sp. 2 \\
\hline H. strigaticeps & $* * * *$ & 0.780 & 0.357 \\
Hypostomus sp. 1 & 0.248 & $* * * *$ & 0.322 \\
Hypostomus sp. 2 & 1.304 & 1.133 & $* * * *$ \\
\hline
\end{tabular}

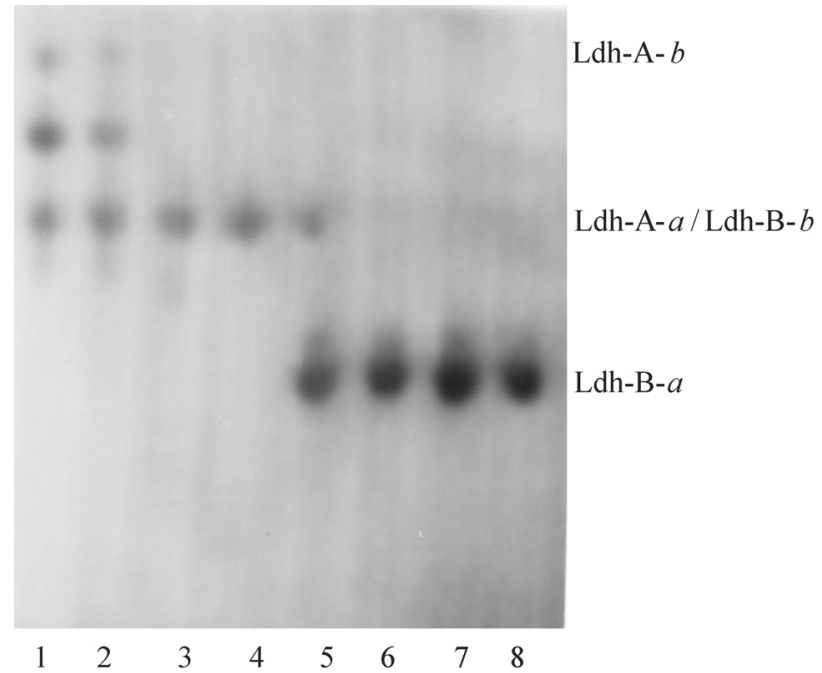

Figure 2 - Lactate dehydrogenase of muscle plus heart tissues of the three Hypostomus populations from Ribeirão Maringá: Hypostomus sp. 1 (1 and 2), H. strigaticeps (3 and 4) and Hypostomus sp. 2 (5 to 8).

plecostomus group sensu Muller and Weber (1992). However, Hypostomus sp. 2 can be allozimically diagnosed from $H$. ancistroides by fixed differences at loci G3pdh-A and G3pdh-B, because Hypostomus sp. 2 has the alleles G3pdh-A- $b$ and G3pdh-B- $b$ while, according to Zawadzki (2001), H. ancistroides from the Itaipu Reservoir has the alleles G3pdh-A- $a$ and G3pdh-B- $a$.

Thus, the allozyme genetic markers found in this work permit us to raise the three populations from the Ribeirão Keller to biological distinct species because, in addition to the morphological differences, they present elevated values of allozyme differentiation and do not share alleles at many of the loci scored. According to Avise and Aquadro (1982) and Richardson et al. (1986), populations differing at about $10 \%$ of loci generally represent distinct species. In fact, Hypostomus sp. 1 and Hypostomus sp. 2 are probably new species of the genus Hypostomus whose taxonomic studies are in process (C.H. Zawadzki and C.S. Pavanelli, personal communication). The status of these three biological species inferred by the electrophoresis technique confirms the usefulness of allozyme data as a tool to discriminate species of the complex family Loricariidae as considered by Zawadzki et al. (1999; 2000; 2002).

As in other fluvial basins of the Neotropics, in the headwater streams of the upper Rio Paraná basin there is a great magnitude variation of morphological and color types of Hypostomus. In addition, many species are cited in the basin (Weber, 1986; 2003) and many usual diagnostic characters often overlap in the many morphotypes or in nominal species of Hypostomus. This phenomenon raises difficulties to the correct identification of the morphotypes and expresses the need for taxonomical revision. From this perspective, biochemical and molecular studies are valuable tools in generating species differentiation by the acquisition of genetic diagnostic markers, as well as insights into the genetic variability and species relationship of Neotropical freshwater fishes.

\section{Acknowledgements}

The authors thank Luis C. Gomes, Laudenir M. Prioli and Maria Cláudia C. R. Takasusuki for reviewing the manuscript, Coordenação de Aperfeiçoamento de Pessoal de Nível Superior (CAPES) for financial support, Weferson J. Graça for help in collecting the samples and Jaime L. Pereira for making the map. We also thank Nupelia for logistic support.

\section{References}

Avise JC and Aquadro CF (1982) A comparative summary of genetic distances in the vertebrates: Patterns and correlations. Evol Biol 15:151-188.

Boyer SH, Fainer DC and Naughton MA (1963) Myoglobin inherited structural variation in man. Science 140:1228-1231.

Fisch-Muller S, Mazzoni R and Weber C (2001) Genetic and morphological evidences for two new sibling species of Ancistrus (Siluriformes, Loricariidae) in upper Rio Tocantins drainage, Brazil. Ichthyol Explor Freshwaters 12:289304.

Gosline WA (1947) Contributions to the classification of the Loricariid Catfishes. Arquivos do Museu Nacional do Rio de Janeiro 41:79-134.

International Union of Biochemistry and Molecular Biology Nomenclature Committee Enzyme Nomenclature (1992) Academic Press, San Diego, pp 729.

Mazzoni R, Caramaschi U and Weber C (1994) Taxonomical revision of the species of Hypostomus Lacépède 1803 (Siluriformes Loricariidae) from the Lower rio Paraíba do Sul, State of Rio de Janeiro Brazil. Rev suis Zool 101:3-18.

Muller S and Weber C (1992) Les dents des sous-familles Hypostominae et Ancistrinae (Pisces Loricariidae) et leur valeur taxonomique. Rev suis Zool 99:747-754.

Murphy RW, Sites JW, Buth DG and Haufler CH (1996) Proteins: Isozyme Electrophoresis. In: Hillis DM, Moritz $\mathrm{C}$ and Mable BM (eds) Molecular Systematics. 2nd edition. Sinauer Associates, Massachusetts, pp 51-120.

Nei M (1978) Estimation of average heterozygosity and genetic distance from a small number of individuals. Genetics 89:583-590.

Reis RE, Weber C and Malabarba LR (1990) Review of the genus Hypostomus Lacépède 1803 from Southern Brazil with descriptions of three new species (Pisces Siluriformes Loricariidae). Rev suis Zool 97:729-766. 
Richardson BJ, Baverstock PR and Adams M (1986) Allozyme electrophoresis: A handbook for animal systematics and population studies. Academic Press, San Diego, pp 410.

Shaw CR and Prasad R (1970) Starch gel electrophoresis of enzymes - A compilation of recipes. Biochem Genet 4:297320.

Solé-Cava AM (2001) Biodiversidade molecular e genética da conservação. In: Matioli SR (ed) Biologia Molecular e Evolução. Holos Editora, Ribeirão Preto, pp 172-192.

Ward RD, Skibinski DOF and Woodward M (1992) Protein heterozygosity protein structure and taxonomic differentiation. Evol Biol 26:73-159.

Weber C (1986) Les poissons-chats cuirassés de la sous-famille des Hypostominae du Paraguay. MS Dissertation University of Nancy, Nancy.

Weber C (2003) Subfamily Hypostominae. In: Reis RE, Kullander SO and Ferraris JR CJ (eds) Check List of the Freshwater Fishes of South and Central America. EDIPUCRS, Porto Alegre, $\mathrm{p} 729$.

Yeh FC and Boyle TJB (1997) Population genetic analysis of co-dominant and dominant markers and quantitative traits. Belgian Journal of Botany 129:157.

Zawadzki CH (2001) Sistemática e variação aloenzimática da família Loricariidae (Teleostei, Siluriformes) dos reservatórios de Corumbá e Itaipu na bacia do alto Rio Paraná, Brasil. PhD Thesis, State University of Maringá, Maringá.
Zawadzki CH, Renesto E and Bini LM (1999) Genetic and morphometric analysis of three species of the genus Hypostomus Lacépède 1803 (Osteichthyes, Loricariidae) from the Rio Iguaçu basin (Brazil). Rev suis Zool 106:91-105.

Zawadzki CH, Reis RE and Renesto E (2000) Allozyme discrimination of three species of Loricariichthys (Siluriformes, Loricariidae) from Southern Brazil. Rev suis Zool 107:1-12.

Zawadzki CH, Machado MFPS and Renesto E (2001) Differential expression for tissue-specific isozymes in three species of Hypostomus Lacépède 1803 (Teleostei, Loricariidae). Biochem Syst Ecol 29:911-922.

Zawadzki CH, Weber C, Pavanelli CS and Renesto E (2002) Morphological and biochemical comparison of two allopatrid populations of Hypostomus margaritifer (Regan, 1907) (Osteichthyes, Loricariidae) from the upper Paraná River basin, Brazil. Acta Scientiarum 24:499-505.

Zawadzki CH, Renesto R, Paiva S and Lara-Kamei MCS (2004a) Allozyme differentiation of four populations of Hypostomus (Teleostei, Loricariidae) from Ribeirão Keller, a stream in the upper Rio Paraná basin, Brazil. Genetica 121:251-257.

Zawadzki CH, Alves AL, Renesto E and Oliveira C (2004b) Biochemical evidence of a possible new species of Neoplecostomus (Teleostei, Loricariidae) from the upper Rio Paraná basin, Brazil. Biochem Syst Ecol 32:573-582.

Associate Editor: Fausto Foresti 